\title{
Histology-Based Morphology of the Neurocentral Synchondrosis in Alligator mississippiensis (Archosauria, Crocodylia)
}

TAKEHITO IKEJIRI*

Museum of Paleontology and Department of Geological Sciences, University of Michigan, Ann Arbor, Michigan

\begin{abstract}
Morphology of the neurocentral synchondroses-thin cartilaginous layers between centra and neural arches-are documented in the extant crocodilian, Alligator mississippiensis (Archosauria, Crocodylia). Examination of dry skeletons demonstrates that neurocentral suture closure occurs in very late postnatal ontogeny (after reaching sexual maturity and/or body size ca. $40 \%$ from the upper range). Before sexual maturity (body length $(\mathrm{BL}) \geq$ ca. $1.80 \mathrm{~m}$ ), completely fused centra and neural arches are restricted to the caudal vertebral series. In contrast, the presacral vertebrae often remain unfused throughout postnatal ontogeny, retaining open sutures in very mature individuals $(\mathrm{BL} \geq 2.80 \mathrm{~m})$. These unfused centra and neural arches are structurally supported by the relatively large surface area of the neurocentral junctions, which results from primarily horizontal (mediolateral) increases with strong positive allometry. Cleared and stained specimens show that the cartilaginous neurocentral synchondrosis starts to form after approximately 40 embryonic days. Histological examination of the neurocentral junction in dorsal and anterior caudal vertebrae of six individuals $(\mathrm{BL}=0.28-3.12 \mathrm{~m}$ ) shows : (1) neurocentral fusion is the result of endochondral ossification of the neurocentral synchondrosis, (2) the neurocentral synchondrosis exhibits bipolar organization of three types of cartilaginous cells, and (3) complex neurocentral sutures (i.e., curved, zigzagged, and/or interdigitated boundaries) come from clumping of bone cells of the neural arches and centra into the neurocentral synchondrosis. The last two morphological features can be advantageous for delaying neurocentral fusion, which seems to be unique in crocodilians and possibly their close relatives, including nonavian dinosaurs and other Mesozoic archosaurs. Anat Rec, 295:18-31, 2012. (C) 2011 Wiley Periodicals, Inc.
\end{abstract}

Key words: vertebra; neurocentral synchondrosis; suture; skeletal fusion; postnatal growth; Alligator

\begin{abstract}
Vertebrae develop from multiple isolated regions of sclerotome cells (Christ et al., 2000) that eventually unite to form a single structural unit after the regions calcify and ossify (Williams, 1959). During this process, the two main vertebral components, the centrum and neural arch, fuse last. Up until their physical contact, the centrum and the neural arch can grow separately, due to different timings of chondrification and ossification (e.g., Christ et al., 2007). The immobile joint
\end{abstract}

\footnotetext{
*Correspondence to: Takehito Ikejiri, Alabama Museum of Natural History, University of Alabama, Tuscaloosa, AL 354870340. E-mail: ikejiri1859@gmail.com

Received 19 March 2011; Accepted 6 September 2011

DOI 10.1002/ar.21495

Published online 18 November 2011 in Wiley Online Library
} (wileyonlinelibrary.com). 


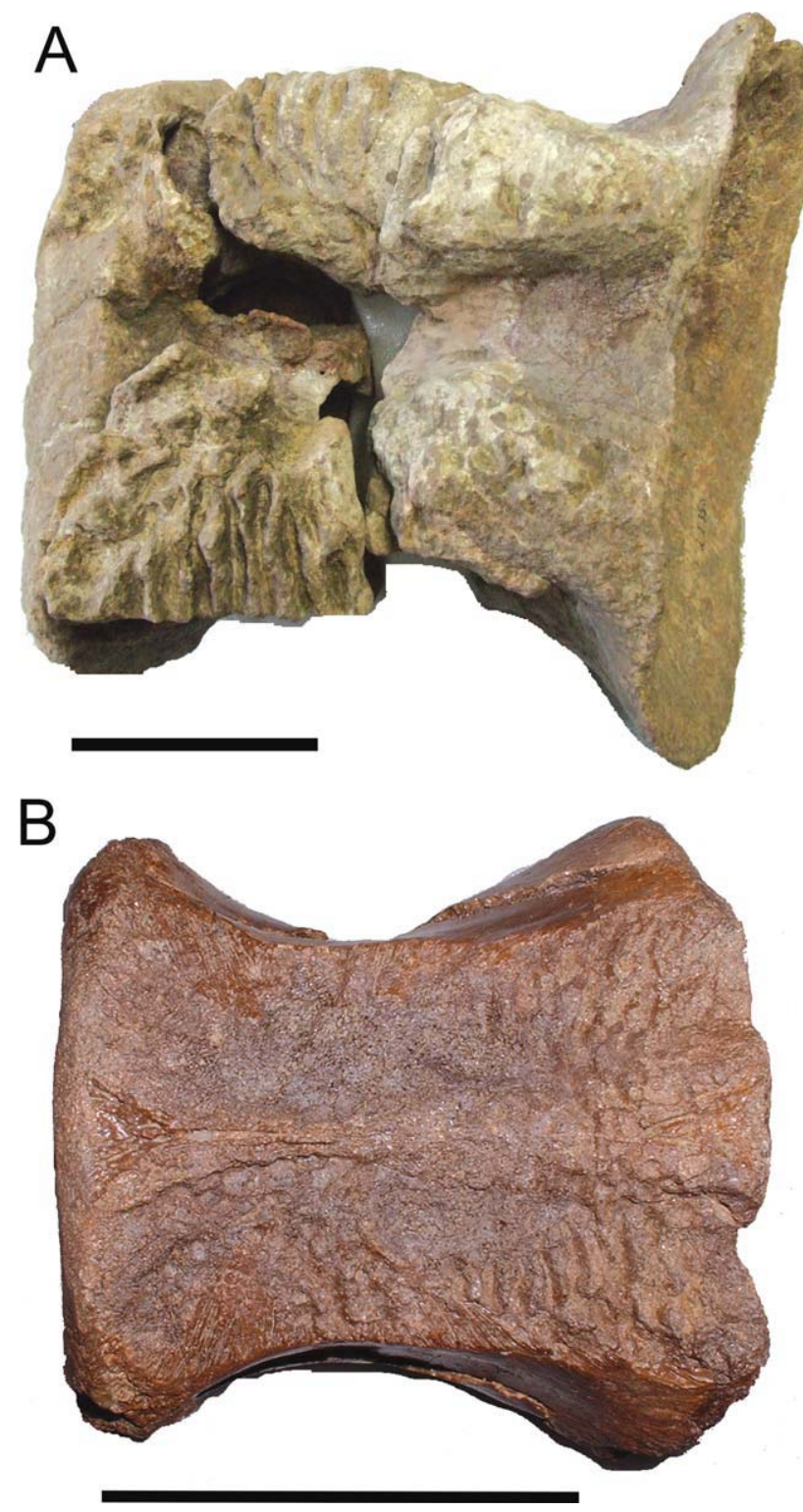

Fig. 1. Centra of large dinosaurs with unfused neural arches. A: sauropod Brachiosaurus (Institut für Paläontologie, Museum für Naturkunde "dd 355" in Berlin). B: Nonavian theropod Tyrannosaurus rex (Royal Tyrell Museum of Paleontology 82.16.122 in Alberta). Both centra show in dorsal view with anterior facing left. The rugose texture is the articular surface of the neurocentral junction. Scales equal $10 \mathrm{~cm}$.

between centrum and neural arch is filled by a thin cartilaginous layer, the neurocentral synchondrosis. Despite its role of vertebral growth, cell-level growth of the neurocentral synchondrosis has not been understood well in vertebrates.

Fusion between centra and neural arches must occur after the result of ossification of the cartilaginous neurocentral synchondrosis. This ontogenetic event tends to appear at a specific ontogenetic stage in each vertebrate species (e.g., 16-20 years in humans; Rajwani et al., 2002). Correct timing of neurocentral fusion is important for vertebral growth. In fact, abnormal timing of neuro- central fusion can produce vertebral malformations, such as asymmetrically sized left and right neural pedicles (Vital et al., 1989), which can contribute to severe axial growth disorders (e.g., scoliosis; Yamazaki et al., 1998).

Among vertebrates, timing of neurocentral fusion varies from the embryonic to the very late postnatal ontogenetic periods, or fusion between centra and neural arches even persists in some taxa throughout life (=patency). Since Brochu (1996) found the pattern of neurocentral fusion (i.e., caudal-to-cervical sequence) in the vertebral column of crocodilians, relatively late timing of neurocentral fusion has been paid special attention to understanding of ontogeny in fossil and extant archosaurs (e.g., archosaurs in general: Cole et al., 2003; pseudosuchians: Irmis, 2007). Notably, the presence of unfused vertebral elements and/or open neurocentral sutures on the external vertebral surfaces has been routinely used to identify relatively immature individuals for especially nonavian dinosaurs (Fig. 1); for example sauropods (Tidwell and Carpenter, 2003; Ikejiri et al., 2005; Schwarz et al., 2007; Kutty et al., 2007), theropods (Carpenter, 1997; Currie and Chen, 2001; Currie and Zhiming, 2001; Carrano et al., 2002, 2005; Carr et al., 2005), ornithischians (Tereshchenko, 2001; Suzuki et al., 2004). However, until intra- and interspecific variation in timing of neurocentral fusion is understood, the nature of the neurocentral sutures as an indicator of relative skeletal maturity remains questionable.

Histology is a powerful way to observe cell- and tissue-level morphology in vertebrate skeletons, but it has been used only infrequently to examine neurocentral synchondroses in vertebrates. The main purpose of this study is to use histology to document cell-level morphology of the neurocentral synchondroses in vertebrae of Alligator mississippiensis (Archosauria, Crocodylia). Hatchling (body length $=0.28 \mathrm{~m}$ ) to fully grown individuals $(=3.12 \mathrm{~m})$ show different patterns of postnatal ontogeny in the presacral and caudal vertebrae. The neurocentral junctions, as well as the surrounding environments, the centra and neural arches along the sutural boundaries, are examined. In addition, dry skeletons and cleared and stained specimens are studied to investigate general patterns of neurocentral fusion in the vertebral column.

Although crocodilians have been known to exhibit late neurocentral fusion (e.g., Mook, 1921; Hoffstetter and Gasc, 1969; Frey, 1988; Rieppel, 1993), timing of neurocentral fusion tends to be variable in the vertebral column. In fully grown crocodilians, the neurocentral junctions are often closed in the caudal and the sacral vertebrae, but the sutures are still visible in the presacral vertebrae (Ikejiri, 2007). Consequently, data from histology of alligator vertebrae may allow discussing key morphologies for fusion versus patency in the neurocentral junctions, which may give some clues for further investigations of the evolutionary significance for delaying timing of neurocentral fusion in archosaurs.

\section{Dry Skeletons \\ MATERIALS AND METHODS}

Seventy-five dry skeletons of Alligator mississippiensis, including those from captive and wild populations, were examined (Table 1). Sutures are often visible on 
TABLE 1. Dry skeletons of Alligator mississippiensis examined for patterns of fusion at neurocentral junction (NCJ)

\begin{tabular}{|c|c|c|c|c|c|}
\hline Specimen & $\begin{array}{c}\text { Femur } \\
\text { length } \\
(\mathrm{mm})\end{array}$ & $\begin{array}{c}\text { Body } \\
\text { length } \\
(\mathrm{mm})\end{array}$ & Sex & $\mathrm{PF}^{\mathrm{a}}$ & $\mathrm{CF}^{\mathrm{a}}$ \\
\hline $\begin{array}{l}\text { UMMZ teaching } \\
\text { ('03956') }\end{array}$ & 18.0 & 277 & $?$ & $\mathrm{Ca} 10$ & $\mathrm{Ca} 10$ \\
\hline USNM 313410 & 18.7 & 287 & ? & $\mathrm{Ca} 8$ & $\mathrm{Ca} 10$ \\
\hline UMMZ 238961 & 19.0 & 291 & $?$ & $\mathrm{Ca} 9$ & $\mathrm{Ca} 9$ \\
\hline TMM M7467 & 19.3 & 295 & $?$ & $\mathrm{Ca} 10$ & $\mathrm{Ca} 10$ \\
\hline TMM M8664 & 23.5 & 356 & $?$ & $\mathrm{Ca} 8$ & $\mathrm{Ca} 9$ \\
\hline AMNH 138124 & 31.6 & 473 & $?$ & $\mathrm{Ca} 9$ & Ca9 \\
\hline UF 35145 & 32.8 & 490 & $\mathrm{M}$ & $\mathrm{Ca} 5$ & $\mathrm{Ca} 7$ \\
\hline UF 35146 & 34.5 & 515 & M & $\mathrm{Ca} 6$ & $\mathrm{Ca} 8$ \\
\hline UF 35144 & 38.0 & 566 & M & $\mathrm{Ca} 6$ & $\mathrm{Ca} 8$ \\
\hline UF 35149 & 39.0 & 580 & $\mathrm{~F}$ & $\mathrm{Ca} 7$ & $\mathrm{Ca} 7$ \\
\hline UMMZ 155216 & 41.3 & 613 & $?$ & $\mathrm{Ca} 7$ & $\mathrm{Ca} 7$ \\
\hline UF 37232 & 44.4 & 658 & $?$ & $\mathrm{Ca} 5$ & $\mathrm{Ca} 7$ \\
\hline UF 40817 & 46.8 & 693 & ? & $\mathrm{Ca} 5$ & $\mathrm{Ca} 5$ \\
\hline UF 11764 & 49.4 & 730 & $?$ & $\mathrm{Ca} 4$ & $\mathrm{Ca} 6$ \\
\hline UF 42475 & 49.8 & 736 & $\mathrm{M}$ & $\mathrm{Ca} 4$ & $\mathrm{Ca} 6$ \\
\hline TMM M6998 & 50.8 & 751 & $?$ & $\mathrm{Ca} 7$ & $\mathrm{Ca} 7$ \\
\hline UF 38973 & 52.4 & 774 & ? & $\mathrm{Ca} 5$ & $\mathrm{Ca} 7$ \\
\hline UF 11127 & 53.1 & 784 & $?$ & $\mathrm{Ca} 4$ & $\mathrm{Ca} 5$ \\
\hline UF 35152 & 55.1 & 813 & $?$ & $\mathrm{Ca} 4$ & $\mathrm{Ca} 5$ \\
\hline USNM 313409 & 55.8 & 823 & M & $\mathrm{Ca} 7$ & $\mathrm{Ca} 8$ \\
\hline UF 109039 & 58.6 & 863 & $?$ & $\mathrm{Ca} 4$ & $\mathrm{Ca} 5$ \\
\hline UF 115605 & 62.4 & 918 & $?$ & $\mathrm{Ca} 6$ & ca6 \\
\hline UMMZ 238965 & 62.8 & 924 & $?$ & $\mathrm{Ca} 4$ & $\mathrm{Ca} 5$ \\
\hline UF 42523 & 63.1 & 928 & $\mathrm{~F}$ & $\mathrm{Ca} 5$ & $\mathrm{Ca} 7$ \\
\hline UF 40769 & 64.6 & 950 & ? & $\mathrm{Ca} 3$ & $\mathrm{Ca} 6$ \\
\hline UF 40535 & 66.5 & 977 & $?$ & $\mathrm{Ca} 4$ & $\mathrm{Ca} 5$ \\
\hline UF 39620 & 68.1 & 1,000 & $?$ & ca5 & $\mathrm{Ca} 6$ \\
\hline UF 38974 & 73.2 & 1,074 & $?$ & $\mathrm{Ca} 4$ & $\mathrm{Ca} 6$ \\
\hline UMMZ 238959 & 74.6 & 1,094 & $\mathrm{M}$ & $\mathrm{Ca} 5$ & $\mathrm{Ca} 6$ \\
\hline UF 38972 & 74.9 & 1,099 & $?$ & $\mathrm{Ca} 5$ & $\mathrm{Ca} 7$ \\
\hline TMM M2433 & 82.5 & 1,209 & $?$ & $\mathrm{Ca} 6$ & $\mathrm{Ca} 6$ \\
\hline UF 39622 & 89.2 & 1,305 & $?$ & $\mathrm{Ca} 4$ & $\mathrm{Ca} 5$ \\
\hline UF 39621 & 90.2 & 1,320 & ? & $\mathrm{Ca} 4$ & $\mathrm{Ca} 5$ \\
\hline UF 39623 & 92.4 & 1,352 & $?$ & $\mathrm{Ca} 2$ & $\mathrm{Ca} 5$ \\
\hline LSUVM 15 & 92.7 & 1,356 & $\mathrm{~F}$ & $?$ & $\mathrm{Ca} 6$ \\
\hline UF 37230 & 96.8 & 1,415 & $\mathrm{~F}$ & $\mathrm{Ca} 4$ & $\mathrm{Ca} 6$ \\
\hline USNM 216198 & 99.9 & 1,460 & $?$ & $\mathrm{Ca} 5$ & $\mathrm{Ca} 5$ \\
\hline LSUVM 16 & 111.3 & 1,625 & M & $\mathrm{Ca} 5$ & $\mathrm{Ca} 5$ \\
\hline TMM M4009 & 112.6 & 1,644 & $?$ & $\mathrm{Ca} 5$ & $\mathrm{Ca} 5$ \\
\hline LSUVM 21 & 112.8 & 1,646 & $?$ & $?$ & $\mathrm{Ca} 5$ \\
\hline LSUVM 17 & 115.3 & 1,683 & $\mathrm{~F}$ & $?$ & $\mathrm{Ca} 5$ \\
\hline LSUVM 19 & 122.6 & 1,788 & $?$ & $?$ & $\mathrm{Ca} 5$ \\
\hline TMM M7487 & 129.1 & 1,882 & $?$ & $\mathrm{Ca} 4$ & $\mathrm{Ca} 4$ \\
\hline USNM 312681 & 132.4 & 1,930 & $?$ & $\mathrm{Ca} 4$ & $\mathrm{Ca} 5$ \\
\hline UMMZ 239623 & 133.8 & 1,950 & $?$ & $?$ & $\mathrm{Ca} 4$ \\
\hline LSUVM 08 & 135.4 & 1,973 & $?$ & $?$ & $\mathrm{Ca} 2$ \\
\hline UF 87886 & 135.5 & 1,974 & $\mathrm{~F}$ & $\mathrm{Ca} 3$ & $\mathrm{Ca} 3$ \\
\hline LSUVM 12 & 135.7 & 1,977 & $\mathrm{M}$ & $?$ & $\mathrm{Ca} 4$ \\
\hline UF 35153 & 137.5 & 2,003 & $?$ & $\mathrm{Ca} 4$ & $\mathrm{Ca} 4$ \\
\hline LSUVM 14 & 141.6 & 2,063 & $\mathrm{M}$ & $?$ & $\mathrm{Ca} 3$ \\
\hline LSUVM 07 & 143.8 & 2,094 & $?$ & $?$ & $\mathrm{Ca} 4$ \\
\hline LSUVM 05 & 151.2 & 2,201 & $?$ & $?$ & $\mathrm{Ca} 3$ \\
\hline LSUVM 13 & 151.9 & 2,211 & $\mathrm{M}$ & $?$ & $\mathrm{Ca} 3$ \\
\hline AMNH 43316 & 156.0 & 2,271 & $?$ & $\mathrm{Ca} 2$ & $\mathrm{Ca} 2$ \\
\hline LSUVM 11 & 157.0 & 2,285 & $?$ & $?$ & $\mathrm{Ca} 4$ \\
\hline USNM 321680 & 158.0 & 2,300 & $\mathrm{~F}$ & $\mathrm{Ca} 2$ & $\mathrm{Ca} 5$ \\
\hline LSUVM 22 & 163.0 & 2,372 & $?$ & $?$ & $\mathrm{Ca} 5$ \\
\hline USNM 312679 & 163.0 & 2,372 & $\mathrm{~F}$ & $\mathrm{Ca} 1$ & $\mathrm{Ca} 3$ \\
\hline TMM 2000-9-15 & 166.0 & 2,415 & $?$ & $\mathrm{Ca} 3$ & $\mathrm{Ca} 3$ \\
\hline LSUVM 18 & 168.0 & 2,444 & $\mathrm{~F}$ & $?$ & $\mathrm{Ca} 2$ \\
\hline UMMZ 239624 & 168.8 & 2,460 & $?$ & $?$ & $\mathrm{Ca} 2(?)$ \\
\hline UF 39106 & 178.0 & 2,589 & $?$ & $\mathrm{Ca} 1$ & $\mathrm{Ca} 2$ \\
\hline
\end{tabular}

TABLE 1. Dry skeletons of Alligator mississippiensis examined for patterns of fusion at neurocentral junction (NCJ) (continued)

\begin{tabular}{lccccc}
\hline Specimen & $\begin{array}{c}\text { Femur } \\
\text { length } \\
(\mathrm{mm})\end{array}$ & $\begin{array}{c}\text { Body } \\
\text { length } \\
(\mathrm{mm})\end{array}$ & Sex & $\mathrm{PF}^{\mathrm{a}}$ & $\mathrm{CF}^{\mathrm{a}}$ \\
\hline USNM 544377 & 178.0 & 2,589 & $\mathrm{~F}$ & $\mathrm{Ds} 15$ & $\mathrm{Ds} 15$ \\
USNM 312673 & 183.0 & 2,661 & $\mathrm{~F}$ & $\mathrm{Ds} 3$ & $\mathrm{Ds} 13$ \\
USNM 211235 & 192.0 & 2,791 & $\mathrm{~F} ?$ & $\mathrm{Ds} 3$ & $\mathrm{Ds} 15$ \\
AMNH R71621 & 194.0 & 2,820 & $?$ & $\mathrm{Sa} 2$ & $\mathrm{Sa} 2$ \\
AMNH R31563 & 208.0 & 3,022 & $?$ & $\mathrm{Ds} 15$ & $\mathrm{Ds} 15$ \\
UF 98341 & 208.0 & 3,022 & $?$ & $\mathrm{Sa} 2$ & $\mathrm{Ca} 1$ \\
UMMZ 239625 & 214.1 & 3,120 & $?$ & $?$ & $\mathrm{Ds} 14$ \\
TMM M8931 & 228.0 & 3,311 & $?$ & $\mathrm{Sa} 2$ & $\mathrm{Sa} 2$ \\
UF109411 & 234.0 & 3,398 & $?$ & Ds2 & Ds15 \\
TMM M4864 & 242.0 & 3,513 & $?$ & Sa1 & Sa2 \\
TMM M4135 & 247.0 & 3,586 & $?$ & $\mathrm{Sa} 1$ & $\mathrm{Sa} 2$ \\
UF 39618 & 262.0 & 3,802 & $?$ & Ds13 & $\mathrm{Sa1}$ \\
UF 134586 & 284.0 & 4,120 & $?$ & Ds3 & Ds4 \\
\hline
\end{tabular}

aPositions of the anteriormost vertebrae with "partially" fused (PF) and "completely fused" (CF) neurocentral junctions are reported. The same data are used for Figure 4.

AMNH, American Museum of Natural History, New York; LSUVM, Louisiana State University, School of Veterinary Medicine; TMM, Texas Memorial Museum University of Texas, Austin; UF, University of Florida Museum of Natural History; UMMZ, University of Michigan Museum of Zoology, Ann Arbor; USNM, United State National Museum, Washington DC.

the external surface of vertebrae in dry skeletons (Fig. 2), providing information about the pattern of neurocentral fusion and how it varies intracolumnarly and ontogenetically. Because dry skeletons of A. mississippiensis are readily available, data can be collected from a large number of specimens.

Two states of fusion, completely fused and partially fused neurocentral junction (Fig. 2) were recorded for each vertebra in 75 skeletons. Completely fused external neurocentral sutures refer to no identical, open space along a line; partially fused neurocentral junctions have a combination of a visible suture lines and bony connections in any parts of sutures. In addition to fusion state, body length, femoral length, and sex were recorded for each specimen (Table 1).

\section{Cleared and Stained Specimens}

Neurocentral junctions were also examined in cleared and stained specimens of Alligator (Table 2). Twelve skeletons were prepared at the University of Michigan Museum of Zoology (UMMZ), including 20 embryonic days to hatchling (ca. 48 days after egg-laying) specimens. They were first cleared with enzyme and then stained by the solutions of alizarin red for bone tissues and alcian blue for cartilage tissues (Dingerku and Uhlers, 1977). Because the specimens are intact, the vertebral column is only visible in lateral view.

\section{Histological Samples}

Three methods have been preferably used in the medical sciences for examinations of the neurocentral junctions: Magnetic Resonance Imaging (MRI; Yamazaki et al., 1998; Rajwani et al., 2002, 2005); radiography (Matt et al., 1996); and Computed Tomography (CT; 
unfused
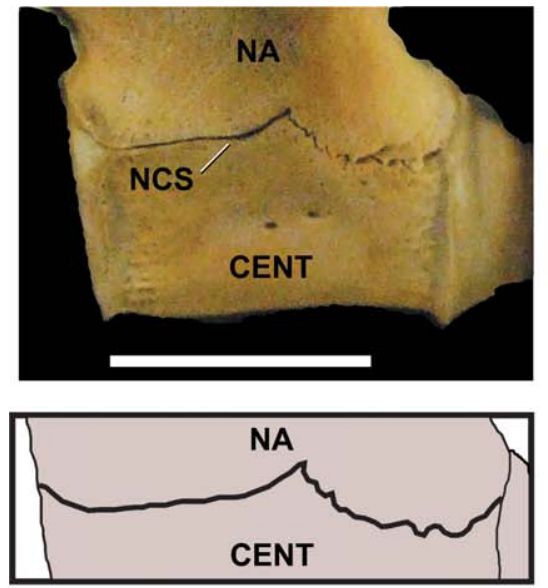

partially fused
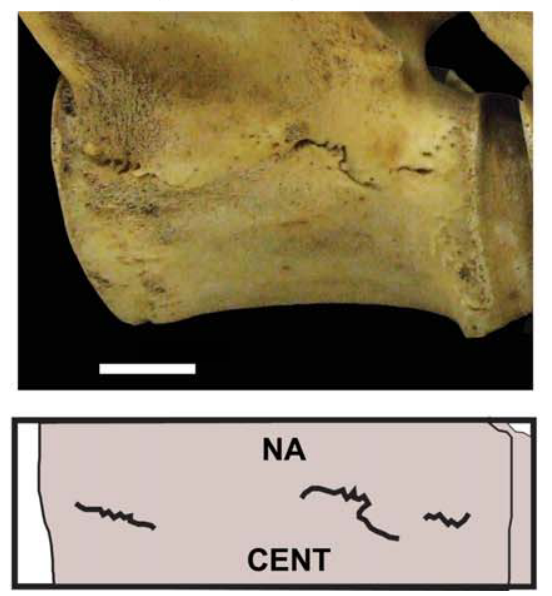

fused
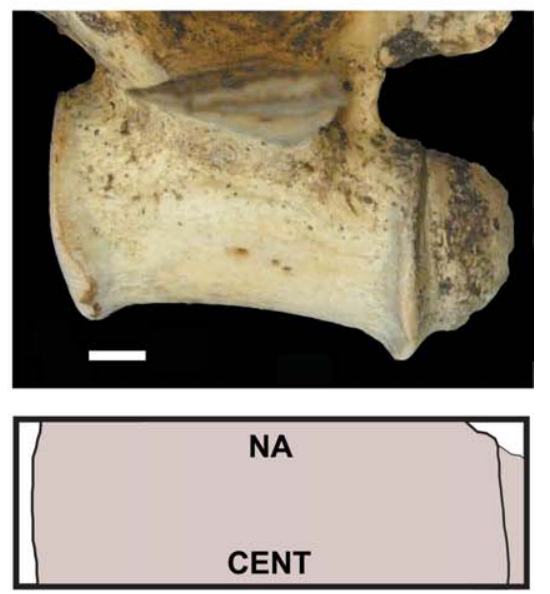

Fig. 2. Transitional changes of neurocentral fusion in posterior dorsal vertebra (no. 13 or no. 14) of Alligator mississippiensis. Left lateral view. Left: Unfused (body length: 1.32 m; UF39621); middle: partially fused (body length: 3.40 m; UF109411); right: completely fused (body length: $4.12 \mathrm{~m}$; UF134586) centrum and neural arch. Additional information of the specimens is available in Table 1. CEN, centrum; NA, neural arch; NCS, neurocentral suture.
TABLE 2. Cleared and stained skeletons of Alligator mississippiensis

\begin{tabular}{lcc}
\hline Specimen & $\begin{array}{c}\text { Age (days after } \\
\text { egg laying) }\end{array}$ & $\begin{array}{c}\text { Femur } \\
\text { length (mm) }\end{array}$ \\
\hline UMMZ 181277 & 20 days & $\begin{array}{c}\text { Not formed } \\
\text { Not formed }\end{array}$ \\
UMMZ 181276 & 20 days & 6.2 \\
UMMZ 181281 & 40 days & 5.8 \\
UMMZ 181282 & 40 days & 5.3 \\
UMMZ 181283 & 40 days & 4.9 \\
UMMZ 121284 & 40 days & $?$ \\
UMMZ 181290 & ca. 48 days (about hatching) & 13.7 \\
UMMZ 181291 & ca. 48 days (about hatching) & 10.8 \\
UMMZ 181292 & ca. 48 days (about hatching) & 13.5 \\
UMMZ 181293 & ca. 48 days (about hatching) & 15.1 \\
UMMZ 181294 & 60 days (12 days after hatch) & 15.9 \\
\hline
\end{tabular}

Vital et al., 1989). These methods are generally limited to identification of the presence or the absence of cartilaginous tissues in the neurocentral junctions, but they do not directly show the types of cells and tissues present in the neurocentral synchondroses. Histology has been used occasionally only in humans and a few lab mammals (e.g., Rajwani et al., 2005), but this method is powerful for examining cell-level morphology of cartilage and bones in general.

Six individuals of the extant crocodilian Alligator mississippiensis were selected for this histological sectioning (vouchers catalogued at UMMZ) (Table 3). The six individuals are determined to include hatchling to fully grown individuals based on the total body length (0.28-3.12 m; Table 3; Fig. 3). Body length was directly measured in the three smaller specimens, and the other three were estimated using the greatest length of the femur (Farlow et al., 2005). Chronological age was estimated based on growth increments in the transverse cross-section of the femora for the three large specimens. Histological preparations are also catalogued at the UMMZ. Sex determination, where known, is listed in Table 3.

Whole skeletons of the three smaller specimens were harvested by Ms. Ruth Elsey (Louisiana Department of Wildlife and Fisheries) for this study from the Rockefeller Wildlife Refuge near Grand Chenier, Louisiana. The three larger specimens were harvested by Mr. Allan "Woody" Woodward (Fish and Wildlife Research Laboratory in Gainesville) and Dr. Kenny Krysko (Florida Museum of Natural History, Herpetology) near Gainesville, Florida during the Florida Statewide Alligator Trapping Program (Rule 68A-25.042). All animals were captured and euthanized according to IACUC guidelines. Skulls, femora, and several vertebrae were transferred to the UMMZ (under Rule 69A-25.52). All six specimens were received freshly frozen, and only those vertebrae were used for the histological sampling. Vertebrae prepared by dermestid beetles provide information to identify cartilage and bone cells, but data from those dry skeletons, which can give inconsistent results (personal observation), are not shown in this study. Skeletons cleaned by bleaching and boiling may severely damage cartilage cells and were not histologically sampled.

A $10 \%$ EDTA solution was used to decalcify the vertebrae enough for slicing and thin-sectioning. Whole vertebrae of the three small individuals were soaked in the solution, but for the three large individuals, vertebrae were coronally sliced along the mid-points crossing the base of the transverse processes and the neural spine prior to decalcification (Fig. 4). A band saw was used to slice each section to about $2-3 \mathrm{~mm}$. These slices were decalcified, and then the site of the neurocentral junction was cut to fit on standard microscopic slide $(7.5 \times$ $2.0 \mathrm{~mm}^{2}$ ). All pieces of the vertebrae were further sliced by microtome to about $5-8 \mu \mathrm{m}$ in thickness for staining. After mounting on a slide, hematoxylin and eosin (H\&E) stain was used to dye bone and cartilaginous tissues. Histological samples were examined using light microscopy (Nikon E800). Magnifications of $2 x-40 x$ were used 
TABLE 3. Summary of histologically sampled specimens of Alligator mississippiensis

\begin{tabular}{|c|c|c|c|c|c|c|}
\hline Body length & Femur length & Age & Sex & $\mathrm{NCF}^{\mathrm{c}}$ & Specimens & Sampled \\
\hline $28 \mathrm{~cm}$ & 19 mm & $<1 \mathrm{yr}$ & n.a. & $\mathrm{Ca} 8-$ & UMMZ 238961 & $\mathrm{Cv} 3, \mathrm{Ds} 14, \mathrm{Ca} 2$ \\
\hline $92 \mathrm{~cm}$ & $62.8 \mathrm{~mm}$ & $\sim 5 \mathrm{yrs}^{\mathrm{a}}$ & Male & Ca 5- & UMMZ 238965 & $\mathrm{Cv} 3, \mathrm{Ds} 14, \mathrm{Ca} 3$ \\
\hline $110 \mathrm{~cm}$ & $74.6 \mathrm{~mm}$ & $\sim 5 \mathrm{yrs}^{\mathrm{a}}$ & Male & Ca 5- & UMMZ 238959 & Ds $14, \mathrm{Ca} 3$ \\
\hline $195 \mathrm{~cm}^{\mathrm{b}}$ & $134 \mathrm{~mm}$ & $20 \mathrm{yrs}$ & $?$ & $?$ & UMMZ 239623 & Ds $14, \mathrm{Ca} 2$ \\
\hline $246 \mathrm{~cm}^{\mathrm{b}}$ & $179 \mathrm{~mm}$ & $30 \mathrm{yrs}$ & $?$ & ? & UMMZ 239624 & Ds $14, \mathrm{Ca} 2$ \\
\hline $312 \mathrm{~cm}^{\mathrm{b}}$ & $214 \mathrm{~mm}$ & $25 \mathrm{yrs}$ & Male? & Sa 1?- & UMMZ 239625 & Ds $14, \mathrm{Ca} 2$ \\
\hline
\end{tabular}

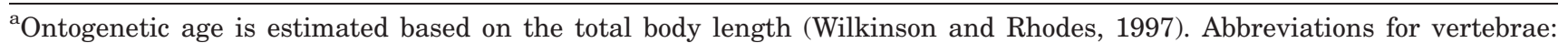
$\mathrm{Ca}$, caudal; $\mathrm{Cv}$, cervical; Ds, dorsal.

${ }^{\mathrm{b}}$ Body length was estimated by the greatest length of the femur following Farlow et al. (2004).

${ }^{\mathrm{c}}$ Neurocentral fusion (NCF) is based on the position of the anteriormost vertebrae with completely fused neurocentral junction (see also Fig. 5).

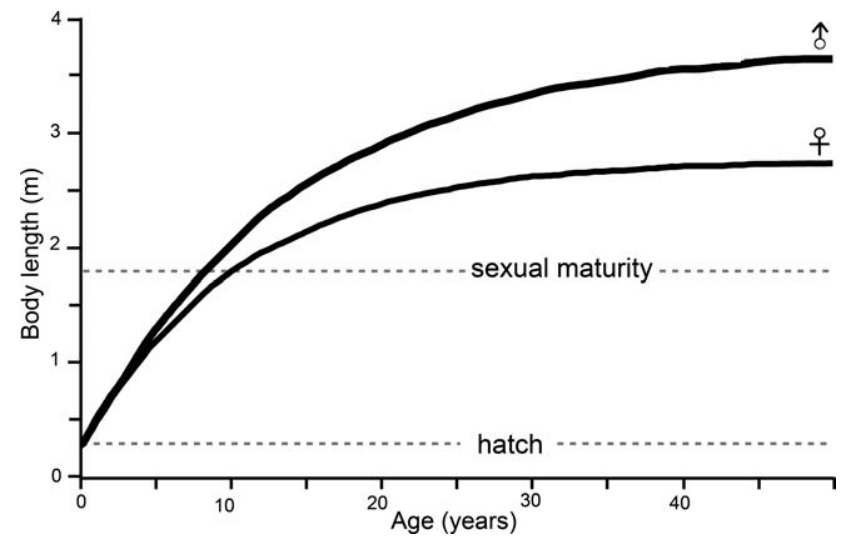

Fig. 3. Growth curve of Alligator mississippiensis. Key ontogenetic events are marked. Skeletal ages based on timing of neurocentral fusion are established using data from Table 1. Growth curve is based on Wilkinson and Rhodes (1997).

for digital photography. Images were saved as TIF files at 600 dpi resolution.

\section{Measurements of Neurocentral Junction}

Transverse width and dorsoventral thickness of the neurocentral junctions were measured in the digital images using ImageJ Version 1.32 (Rasband, 2003; Abramoff et al., 2004). The transverse width is the straight distance between the lateral and medial margin of the cartilaginous synchondrosis. The thickness was measured at the thickest (maximum) and thinnest (minimum) spots, and then, the mean was calculated. All measurements were log-transformed. Using a leastsquares method, allometric coefficients were calculated in the log-log plots (total body length on the $X$-axis and the vertebral dimensions on the $Y$-axis). The slopes allow identifying either isometric (i.e., the slope between 0.951 and 1.049) or allometric growth (slope outside of the above values).

\section{RESULTS \\ Patterns of Neurocentral Fusion in Dry Skeletons}

Seventy-five dry skeletons of Alligator mississippiensis across a postnatal ontogenetic range (Table 1) were examined to construct a sequence for closure of the external neurocentral sutures during postnatal ontogeny (Fig. 5). Among the 75 post-hatchling individuals, caudal 10 is the anterior-most vertebrae with open neurocentral sutures. At least in the ten anterior-most caudal vertebrae, neurocentral fusion progresses in a unidirectional posterior-to-anterior sequence, as observed by Brochu (1996). Neurocentral fusion is completed in the anteriormost caudal vertebrae after sexual maturity (body length = ca. $1.8 \mathrm{~m}$; Fig. 3). The sutures disappear completely in the two sacral vertebrae by the time alligators reach $2.50 \mathrm{~m}$ total body length, which is nearly maximum size for females and about $70 \%$ maximum size for males. In contrast to the caudal vertebrae, neurocentral fusion tends to occur in the anterior-to-posterior sequence in the sacral region, where the anterior sacral vertebra exhibits slightly earlier fusion than the posterior sacral vertebra (Fig. 5).

In most individuals of Alligator, completely fused centra and neural arches are rarely found in presacral vertebrae (Fig. 5). In the 75 specimens examined, only very large individuals (body length over $2.50 \mathrm{~m}$ ) exhibited completely fused neurocentral sutures in any presacral vertebrae. In three of these, only the posteriormost dorsal vertebra is fused. Four of these have partially fused neurocentral junctions in the mid- and anterior dorsal vertebrae. These patterns indicate that neurocentral suture closure in dorsal vertebrae occurs in a relatively short time among the fully grown individuals. It is difficult to determine a "typical sequence" of fusion in the presacral vertebrae, as Brochu (1996) suggested reported in the combination of Alligator mississippiensis, Alligator sinensis, Crocodylus actus, and Osteolaemus tetraspis. Even in the largest individual (body length $=4.2$ $\mathrm{m}$; ca. 40 years old), the sutures are fully open in all cervical vertebrae (Figs. 3 and 5 ).

\section{Embryonic Vertebrae from Cleared and Stained Specimens}

Cleared and stained specimens allow direct identification of bone and cartilage tissues in vertebrae, as used in embryonic to hatchling alligators (Rieppel, 1993). In specimens of 20-day-old embryos of Alligator mississippiensis (UMMZ 181276, 181277), all centra are largely cartilaginous, but the neural arches are not fully chondrified. No evidence of cartilaginous neurocentral junctions is found.

Cartilaginous neurocentral joints are visible in 40-dayold embryos (Fig. 6), which are about eight days from hatching (Ferguson, 1985). Cartilaginous layers, stained 


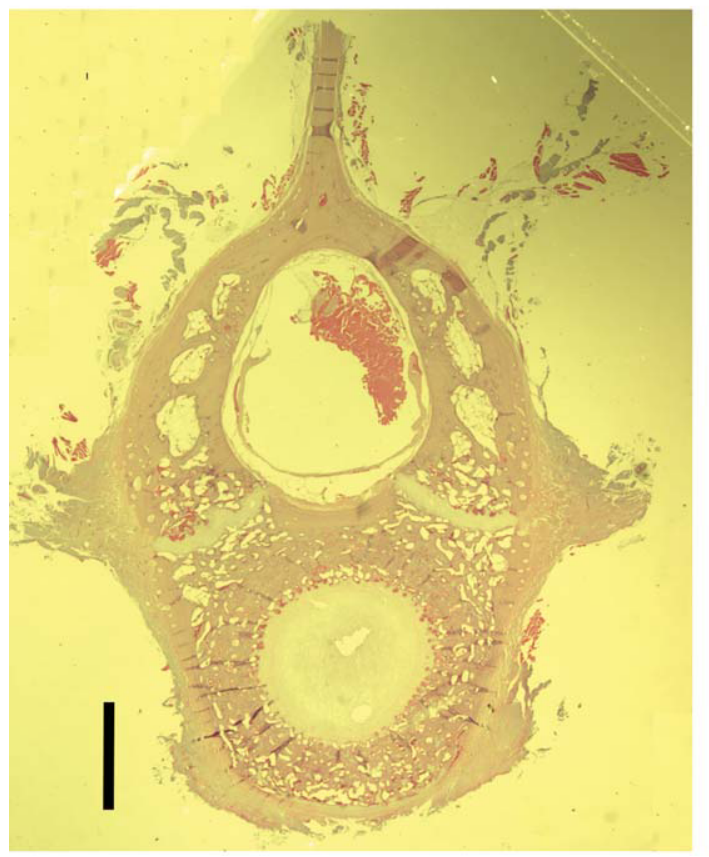

Fig. 4. Histologic section of anterior caudal vertebra of Alligator mississippiensis. Caudal 3 (body length $=0.9 \mathrm{~m}$ : UMMZ 238965) was coronally sectioned and stained with hematoxylin and eosin (H\&E). Light red color indicates bone; light pink and grey represents cartilage. Identification of key vertebral parts is shown in the illustration, includ-

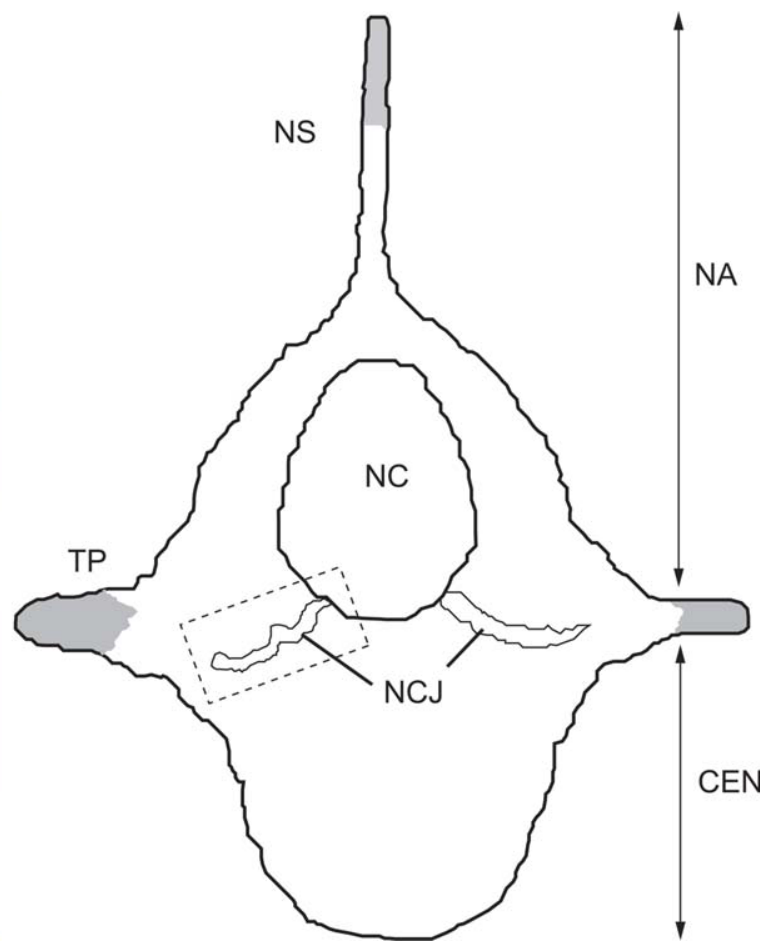

ing: CEN, centrum; NA, neural arch; NC, neural canal; NCJ, neurocentral junction; NS, neural spine; TP, transverse process. The dashed box indicates the area around the neurocentral junction (more details in Fig. 7). Gray shaded areas are missing parts due to sectioning of the vertebra.

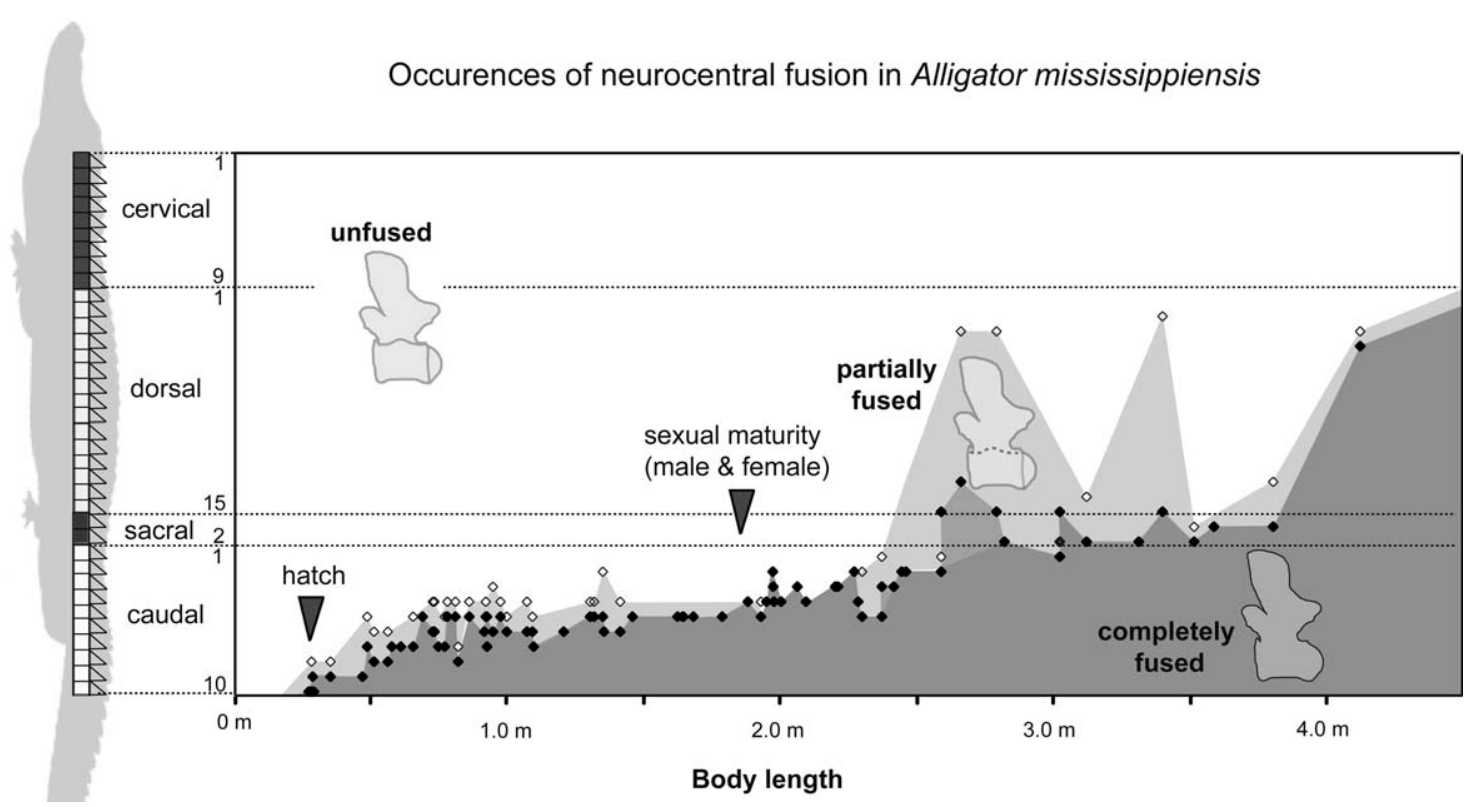

Fig. 5. Occurrences of neurocentral fusion during postnatal ontogeny of Alligator mississippiensis. The dots indicate the positions of the anteriormost vertebra with completely and partially fused neurocentral sutures along the $\mathrm{Y}$-axis for each individual (male and female are not separated). The gray area represents a 'fused' zone according to individuals with the highest number of vertebrae with fused vertebrae.
The three states of fusion are shown in Figure 2. The body length is estimated by the total femoral length (Farlow et al., 2004). Ontogenetic age is estimated by the total body length (Wilkinson and Rhodes, 1997). Timing of sexual maturity follows Ferguson (1985). Specimens are listed in Table 1. 

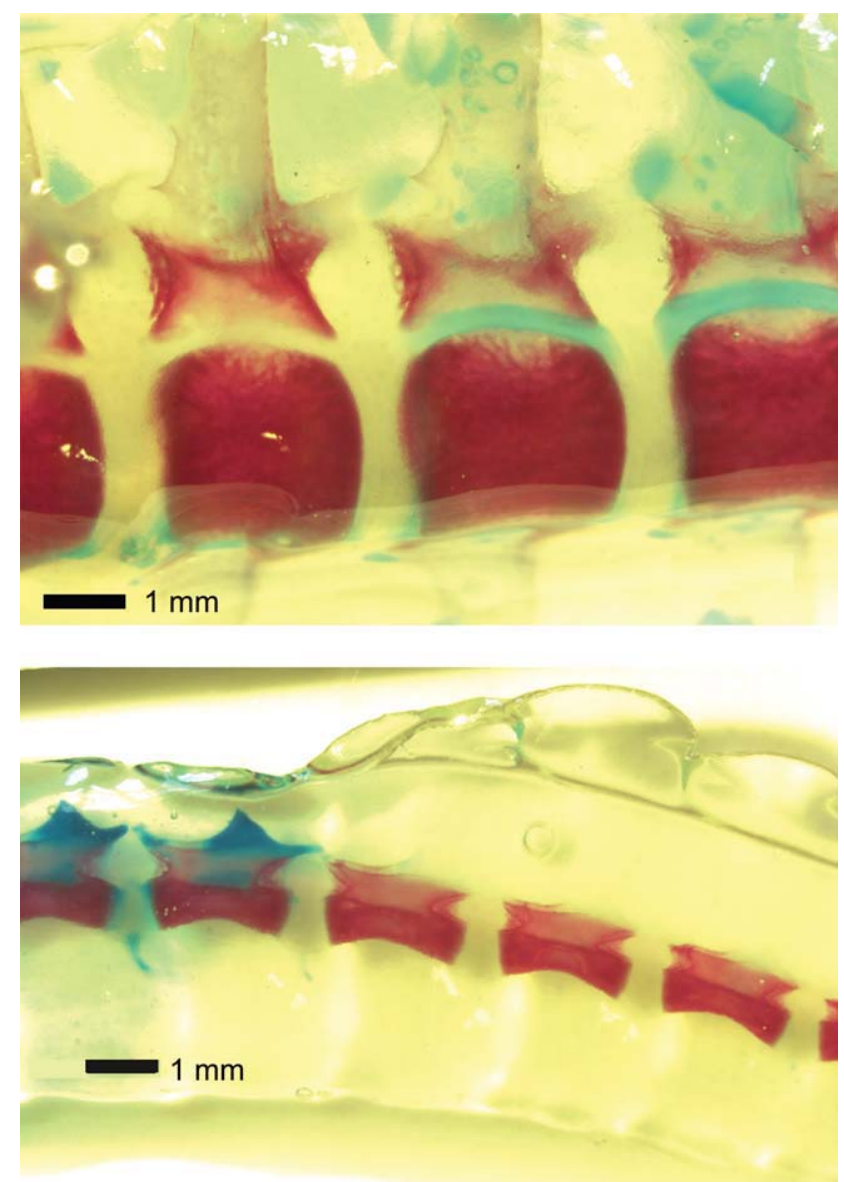

Fig. 6. Vertebrae of 40 days-old embryonic Alligator mississippiensis. Cleared and stained specimen (UMMZ 18192) of top, the four anterior dorsal vertebrae and bottom, some posterior caudal vertebrae. Left lateral view.

in blue, are identifiable in lateral view of the presacral to mid-caudal vertebrae. While ossified regions (stained in red) appear in the centra of all vertebrae, the neural arches are still largely cartilaginous. A gap in timing of chondrification and ossification exists between centra and neural arches. Ossification has already started in the large portion of the centra and some portions of the neural arches.

The 40-day-old embryo (UMMZ 18192) shows a more advanced feature of the neurocentral junctions in the vertebral column. In the mid-dorsal vertebrae, a thick, cartilaginous neurocentral synchondrosis $(0.248 \mathrm{~mm}$; centrum height $2.31 \mathrm{~mm}$ ) is present between the centra and the neural arch (Fig. 6). Notably, in the cervical and two anterior dorsal vertebrae, there is an open space between centra and neural arches (Fig. 6). This feature may indicate the neurocentral synchondrosis is possibly formed as secondary cartilage (i.e., chondrification occurs after ossification of the centrum and neural arch) in Alligator, which has not been reported previously in nonavian archosaurs and other reptiles (Hall, 2005).

In posterior caudal vertebrae, the 40-day-old embryos have no cartilaginous boundaries in the neurocentral junctions (Fig. 6). The centra and neural arches in at least several posteriormost caudal vertebrae have highly ossified entire vertebral structure. Because these vertebrae lack neural canals, they may simply lack the neurocentral junction, but the entire vertebrae chondrify and ossify from a single piece.

\section{Histology of Centrum and Neural Arch}

In coronal cross-section, alligator vertebrae exhibit very similar topology among the centrum, neural arch, neural canal, and neural spine (Fig. 4). Although the shape and size of vertebrae vary in the vertebral column (Mook, 1921; Hoffstetter and Gasc, 1969), the neurocentral junction is always placed in between the centra and the neural arch. In crocodilians, the junction is located near the lower portion of the neural canal, and left and right junctions never contact one another.

Transverse processes form differently in the presacral, sacral, and caudal vertebrae (Higgins, 1923). In the presacral vertebrae, the transverse processes develop as an outgrowth of the neural arch. In contrast, in the sacral and caudal vertebrae, the transverse processes have a separated ossification center. In crocodilians, these "free caudal ribs" attach to the lateral surface of both centrum and neural arch across the neurocentral junction. An anterior caudal vertebra of the subadult Alligator mississippiensis (Fig. 4) has thin cartilaginous layers present in the junctions among the neural arch, centrum, and ribs.

Figure 7 shows coronal sections of the entire neurocentral junction of dorsal vertebra 14 and caudal vertebra 2 or 3 from five individuals of Alligator mississippiensis. In the hatchling (body length $=0.28$ $\mathrm{m}$ ), compact bone is already present in the external walls of the vertebra along the neurocentral junction, but cartilage is still the main component of the entire vertebra. Notably, a sharp gap in timing of endochondral ossification exists in between centra and neural arches: cartilaginous tissues largely occupy within the internal space of the neural arches, but osteoblast cells occur in large proportions of the centra. Moreover, a trabecular structure starts to appear in the entire vertebra of the hatchling. The differences in internal cell and tissue formation between the centrum and neural arch make the neurocentral junction identifiable under $2 \mathrm{x}-4 \mathrm{x}$ magnification.

In the juvenile (body length $=0.92 \mathrm{~m}$ ), ossification is not yet complete in both centra and neural arches. The centrum exhibits a large cartilaginous space, which occupies about half of the cross-sectional area. However, compact bone structure appears in the external wall of both centrum and neural arch (Fig. 7). This dense compact bone occurs in parts of the neural spine, the transverse processes, and the inner wall along the neural canal. Relatively large marrow spaces are found near the bases of the centra and neural arches, forming a trabecular structure along the neurocentral junctions. Many bright red spots, representing osteoblasts and osteoclasts, indicate newly forming bone cells. These cells are dominant along the boundary between neurocentral junction and base of the centrum or neural arch.

The young adult (body length $=2.0 \mathrm{~m}$ ) shows that further ossification in the dorsal and the caudal vertebrae 

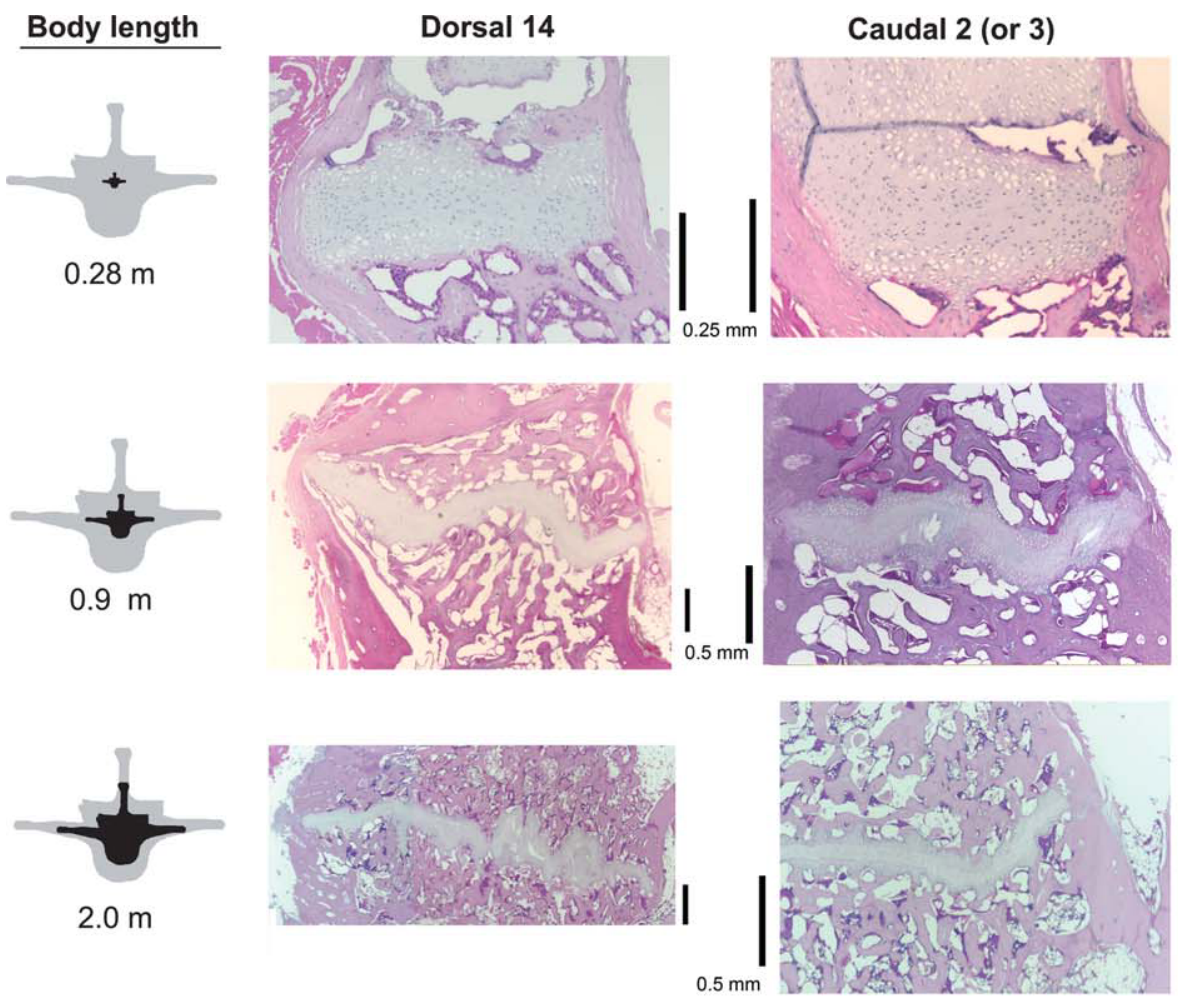

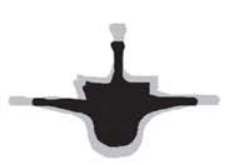

$2.5 \mathrm{~m}$

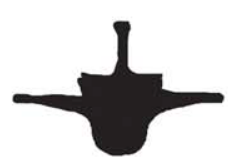

$3.2 \mathrm{~m}$
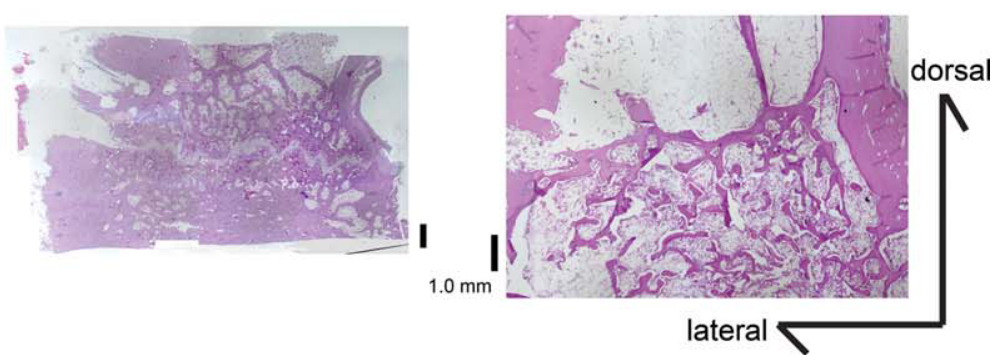

Fig. 7. H\&E stained histologic sections of neurocentral junction of Alligator mississippiensis. Dorsal 14 (left column) and caudal 2 or 3 (right column) were sectioned coronally. The five individuals represent hatchling (upper row) to fully grown individuals (lower row): UMMZ 238965, 238959, 239623, 239624, and 239625, respectively. The ver-

(Fig. 7). The compact woven bone thickens in the external vertebral walls, and the degree of trabecular structure increases in both centra and neural arches. In the two large adults (body length $=2.5 \mathrm{~m}$ and $3.1 \mathrm{~m}$ ), the internal structure of vertebrae is similar to those of the young adult. The external bone walls on lateral surfaces and along the neural canal tend to be thicker through ontogeny in Alligator. tebral silhouettes show a comparison of size based on the largest individual. Note: the large portion of the neural arch was accidentally removed during the process of thinsectioning in the caudal vertebra of UMMZ 239625.

\section{Histology of Neurocentral Junction}

Overall size and cross-sectional shape. Histology shows that the neurocentral synchondrosis is identical in all but the caudal vertebra of the largest individual (Fig. 7). Overall, the neurocentral synchondrosis is transversely thin and sheet-like in coronal cross-section. The neurocentral synchondroses remain relatively the same dorsoventral thickness throughout the postnatal 
TABLE 4. Measurements of neurocentral junctions (NCJ) in growth series of Alligator mississippiensis

\begin{tabular}{|c|c|c|c|c|c|c|}
\hline Specimens & $\begin{array}{l}\text { UMMZ } \\
238961 \\
\end{array}$ & $\begin{array}{l}\text { UMMZ } \\
238965 \\
\end{array}$ & $\begin{array}{l}\text { UMMZ } \\
238959 \\
\end{array}$ & $\begin{array}{l}\text { UMMZ } \\
239623 \\
\end{array}$ & $\begin{array}{l}\text { UMMZ } \\
239624 \\
\end{array}$ & $\begin{array}{l}\text { UMMZ } \\
239625 \\
\end{array}$ \\
\hline Body length & 280 & 920 & 1100 & 1950 & 2460 & 3120 \\
\hline NCJ width & 0.8 & 4.3 & 4.8 & 9.2 & 14.8 & 21.6 \\
\hline NCJ thickness (minimum) & 0.24 & 0.25 & 0.25 & 0.45 & 0.50 & 0.66 \\
\hline NCJ thickness (maximum) & 0.35 & 0.56 & 0.61 & 0.67 & 0.83 & 0.88 \\
\hline NCJ thickness (mean) & 0.30 & 0.41 & 0.43 & 0.56 & 0.67 & 0.78 \\
\hline
\end{tabular}

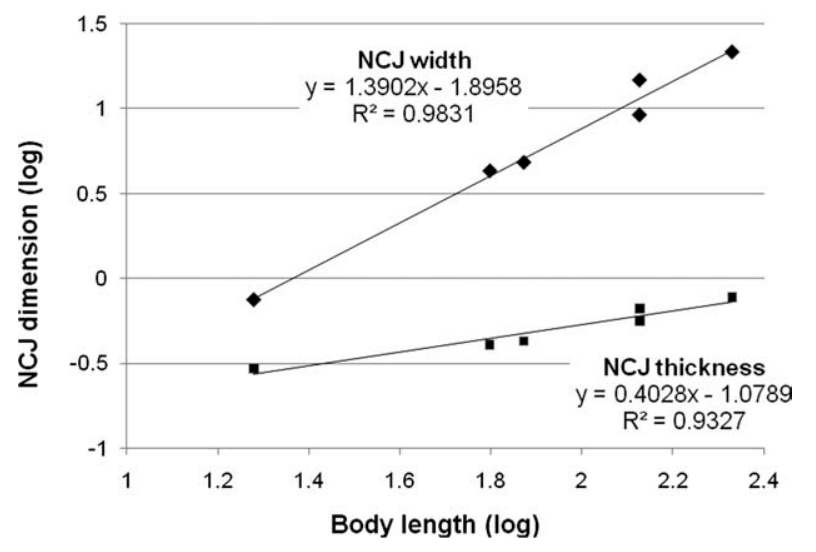

Transverse width is measured between the lateralmost and medialmost points in the coronal cross section of vertebrae (see Fig. 7). The vertical thickness was measured at the minimum and the thickest point. All measurements (in mm) were logtransformed and using a least-squares method, allometric coefficients of the log-log plots are calculated separately in "NCJ width" and "NCJ thickness" (median) on the $Y$-axis relative to the total "body length" on the $X$-axis as shown in the graph (below).

ontogeny. Maximum dorsoventral thickness ranges from 0.35-0.88 $\mathrm{mm}$ in the sutures, which exhibits strong negative allometry from the hatchling to large adult (Table 4). In contrast, the transverse width of the neurocentral junction indicates positive allometric change among the six individuals (allometric coefficient $=1.33$; Table 4 ).

During postnatal growth, the caudal and the dorsal vertebrae show two main types of morphological changes in the neurocentral junctions, such as remodeling (tissue turnover) and modeling (shaping) of cells. In caudal vertebrae of the very large Alligator (body length $=3.12 \mathrm{~m}$; Fig. 7), the cartilaginous boundary does not exist and only bony tissues are found spanning the neurocentral junction. This feature indicates a change from the synchondroid cartilage to endochondral bone tissue. Notably, a clear cartilaginous synchondroid layer still remains in the posterior dorsal vertebra of the same fully grown alligator. The same pattern is found in some very large individuals of the dry skeletons (Fig. 5; Table 1).

The second type of ontogenetic change is observed in the overall cross-sectional shape of the neurocentral junctions. The hatchlings show much fewer numbers of directly connected sites (or smaller direct articular surface relative to the entire neurocentral junctions) between neurocentral synchondrosis and centrum or neural arch than the adults. Furthermore, in the three adult individuals (Fig. 7), a relatively straight shape forms in the caudal vertebrae, but vertically curved, zigzagged articulations exist in the dorsal vertebrae. Because the young individuals have straight neurocentral junctions, this vertical transformation of the neurocentral boundary is likely due to cell migrations.
Cell types of neurocentral synchondrosis. Detailed cellular morphology of the neurocentral synchondrosis can be observed under $4 \mathrm{x}-40 \mathrm{x}$ magnification. In Alligator mississippiensis, the neurocentral synchondrosis consists of three main types of cartilage cells: reserve cartilage (RC), proliferating cartilage (PC), and calcified cartilage (CC) cells (Fig. 8). Reserve cartilage cells are relatively small with identical nuclei. In the hatchling (Fig. 8, left column), those circular or angular cells are condensed and placed in the mid-zone of the neurocentral synchondrosis. Although the cells are crowded in the zone, no clear orientation of cell formation occurs in the hatchling stage. Proliferating cartilage cells are large and unnucleated. They are usually rounded and found in both upper and lower zones along the mid-zone with reserve cartilage, forming a "bipolar" structure. Calcified cartilage cells, which appear light gray or blue under H\&E stain, are formed in the outer-most layers of the neurocentral synchondroses. Structure of individual cells is usually not identical, but some cells still possess nuclei, indicating a relatively rapid rate of growth (calcification). The calcified cartilage tissues have denser structure and finer texture than the two other types of the synchondroid cartilaginous tissues. The calcified cartilage is also found in parts of the centrum and the neural arch along the suture. Cells stained dark red, which indicate osteoblasts, form a large proportion of the centrum and the neural arch, but are absent in the neurocentral junction. Those newly formed bone cells occur along the calcified cartilage layers of the neurocentral junction.

The subadult alligator (Fig. 8, middle column) has the same three cartilaginous zones with bipolar 

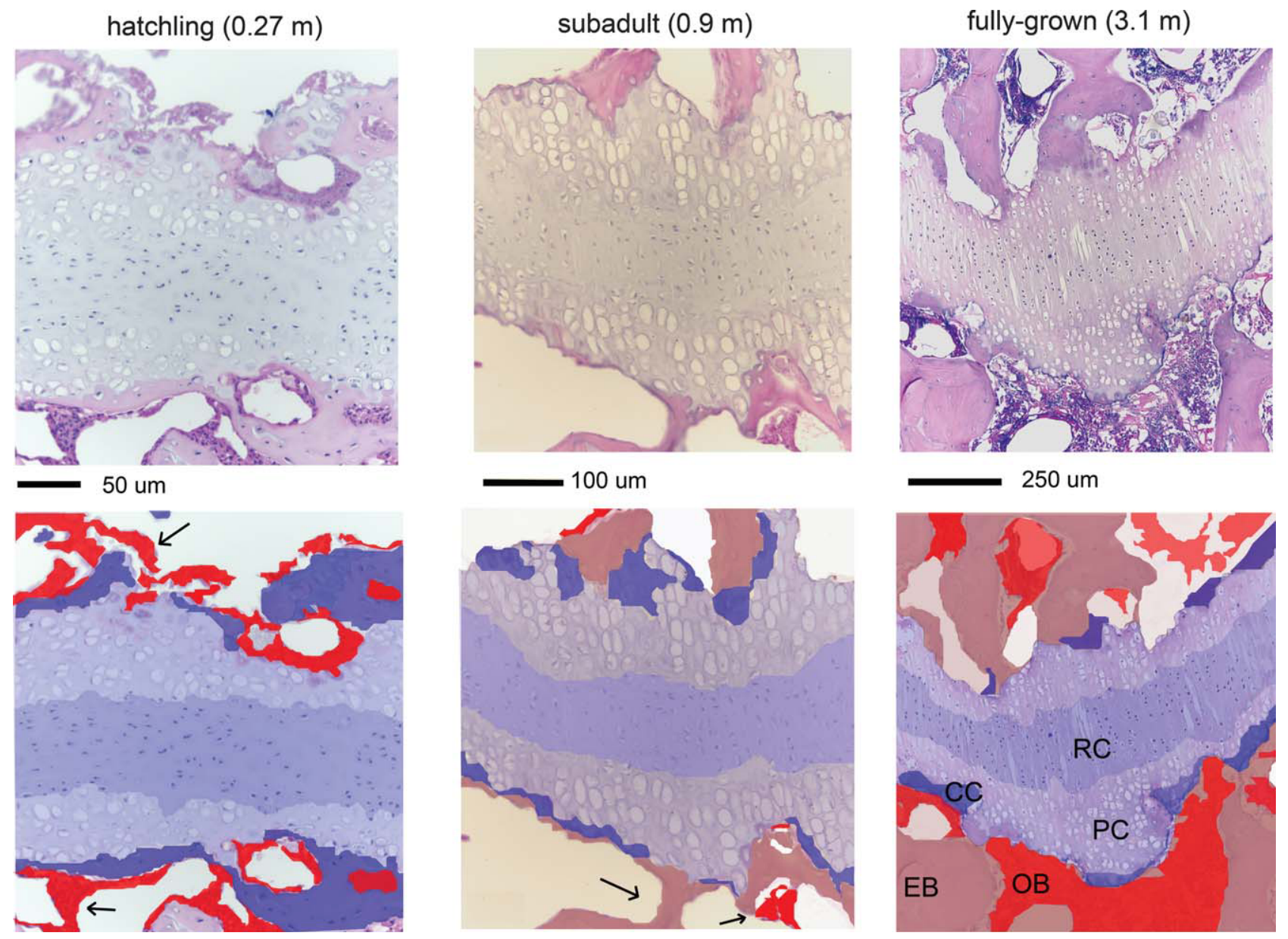

Fig. 8. Microscopic morphology of neurocentral junction in Dorsal 14 of Alligator mississippiensis. Left column: hatchling (body length = $0.27 \mathrm{~m}$; UMMZ 238961), middle column: subadult (body length = $0.9 \mathrm{~m}$; UMMZ 238959), and right column: fully grown (body length = $3.1 \mathrm{~m}$; UMMZ 239625) individuals. Coronal cross-sectional view. Upper row: photomicrograph of H\&E stained histologic section. Lower

row: identification of key cells and tissues (interpreted based on the photo images). The neurocentral synchondrosis shows bipolar structure of cartilaginous cell layers along the mid-zone (reserve cartilage layer). Abbreviations for bone and cartilage: CC, calcified cartilage; EB, endochondral bone; HC, hypertrophic cartilage; OB, osteoblast; OCL, osteoclast; PC, proliferating cartilage; RC, reserve cartilage.

structure in the neurocentral synchondrosis. Notably, reserve and proliferating cartilage cells start to be arranged vertically in long parallel columns, called lacunae. The reserve cartilage cells are still placed horizontally in the mid-level of the neurocentral synchondrosis with a relatively consistent thickness, but showing a weakly curved overall shape. The proliferating cartilage cells lack nuclei and are slightly larger than the reserve cartilage cells. These features indicate that hypertrophy occurs along the vertical axis towards the outer zones. This second outer layer(s) has a greater range of the vertical cell migration in the neurocentral synchondrosis. This inconsistency in vertical thickness forms curvature of the overall synchondroid layer and complex articular surfaces between neural arches and centra. As shown in areas of the calcified cartilage tissues, more extensive calcification occurs along the outer layers of the neurocentral synchondroses. Osteoblast cells continuously form along the calcified cartilage layer in the centrum and especially in the neural arch. Notably, a higher number of direct bony and/or calcified connections between the neurocentral synchondrosis and centra or neural arch are found in this individual than the hatchling. The increase in direct connection provides larger cross-sectional articular surface areas between centra and neural arches during postnatal ontogeny. Newly formed and ongoingbridges between the neurocentral synchondrosis and the two main vertebral parts can be also observed in the vertebra (arrows in Fig. 8).

The adult alligators have the same bipolar cell structure with some minor modification (Fig. 8, right column). The reserve cartilage zone is strongly curved relative to the horizontal axis. Importantly, the cartilage cells are regularly lined up to the vertical axis as shown in the subadult, indicating the shaping of the synchondroid layers does not affect polarity of those cartilaginous cells along the axis. In cross-section, the thickness of the synchondroid cartilage layer is highly variable, especially in adults. Some portions are thinner (and gently pinched) than others in the entire synchondrosis. The cross-sectional area of direct calcified and/or bony connections to 


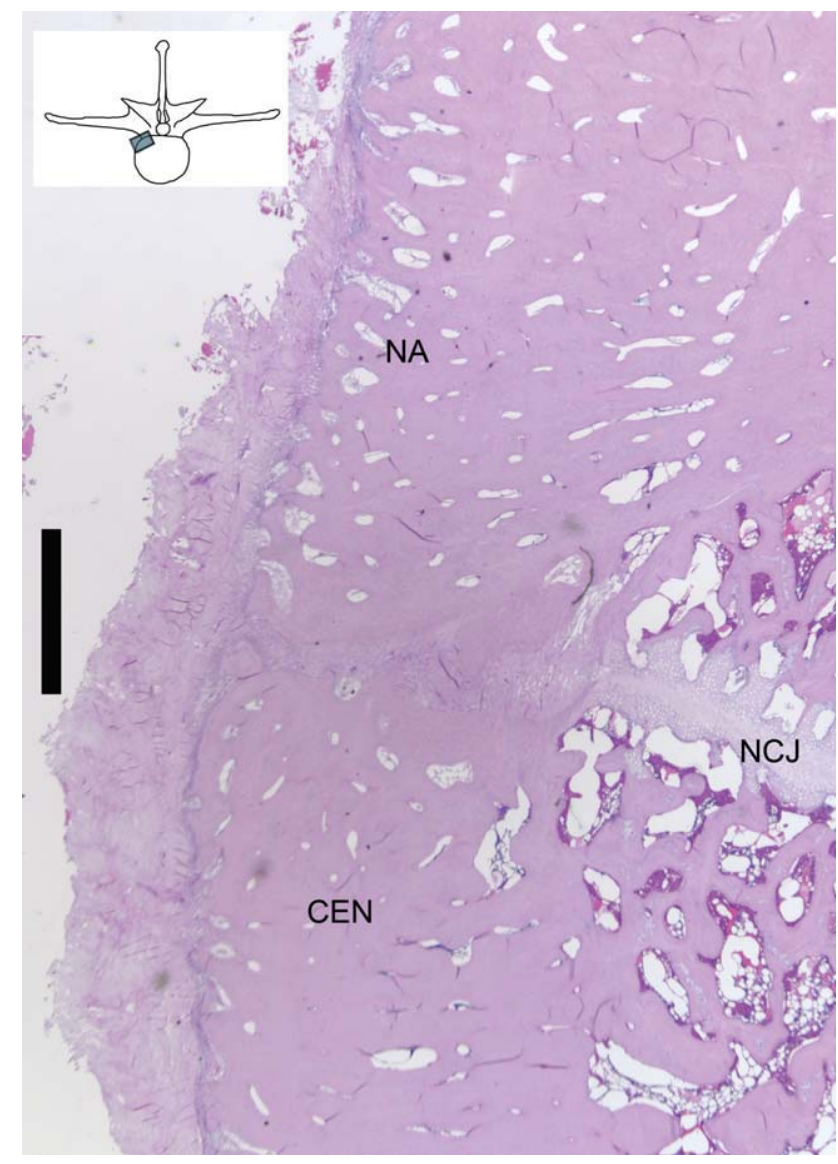

Fig. 9. External wall of vertebrae along neurocentral junction in Alligator mississippiensis. Dorsal 14 of a fully grown individual (UMMZ 239624). Coronal cross-sectional view shows a bony boundary in the external vertebral wall, which is directly connected to the cartilaginous suture in the internal vertebral structure. CEN, centrum; NA, neural arch; NCJ, neurocentral junction. Scale equals $1 \mathrm{~mm}$.

centra or neural arches (arrows in Fig. 8) increases in this stage. Besides synchondroid cell migration into bone tissues of the centrum and neural arches, bone cells of the centra and neural arches also migrate to the neurocentral synchondroid layer. The combination of cell migration from both neurocentral synchondroses and centra or neural arches produces those highly zigzagged outlines of the sutural boundary.

Neurocentral suture in the external vertebral wall. The external margin of the neurocentral junction is covered with fibrous sheath (e.g., periosteum, perichondrium) (Fig. 9). This particular site is distinguishable from other portions of the vertebral walls, as observed sutures. Unlike the regular vertebral wall, which has homogeneous dense compact bone, the external margin of the neurocentral suture bears small nucleated osteoblast cells and newly formed calcified layers (avascular tissue). Many fine, overlapping layers are present, indicating a relatively rapid rate of bone formation, as similarly found at sites of bone fracture during a healing period. Notably, the presence of the neurocentral synchondrosis (or any related cartilaginous cells) in the internal structure of vertebrae is directly linked to these unique external features among

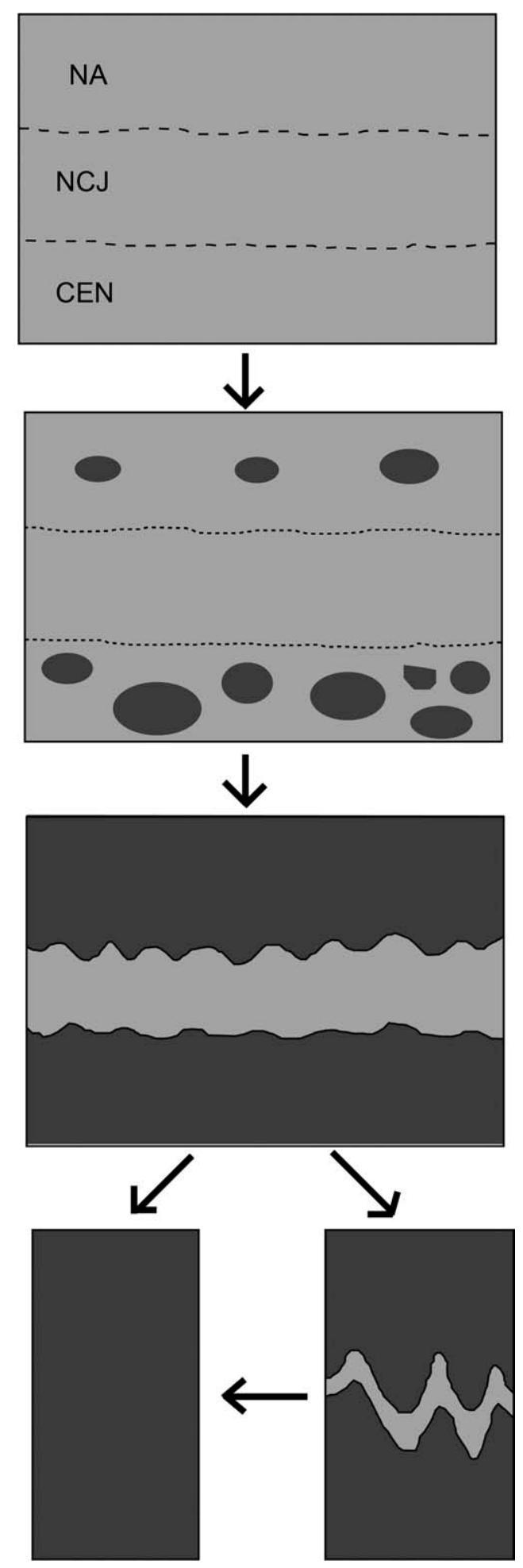

Fig. 10. Diagramic representation of four stages of neurocentral fusion in caudal vertebrae of Alligator mississippiensis. The first stage represents the hatchling period. The bottom represents the very mature stage in caudal vertebrae (left) or presacral vertebrae (right). Dark gray indicates bone and light gray indicates cartilage cells. Abbreviations for vertebral parts: CEN, centrum; NA, neural arch; NCJ, neurocentral junction. 
'unfused', 'partially fused', and completely 'fused' stages (Fig. 2). When the neurocentral synchondrosis is completely ossified, the external margin is no longer distinguishable as seen in the dorsal vertebrae of the fully grown individual.

\section{DISCUSSION}

Among tetrapods, Alligator and other crocodilians have drastically delayed neurocentral fusion in the presacral vertebrae (i.e., after reaching sexual maturity and/or body size ca. $40 \%$ from the upper range in the species; Fig. 5). Histology of vertebrae shows that Alligator has bipolar organization of the synchondroid cartilaginous layers and vertical cell migration of neurocentral synchondroses and bone cells of centra and neural arch along the neurocentral sutures. Possibly, the two features are related to each other and provide environments of delaying fusion between centra and neural arches in presacral vertebrae during growth. Relatively late timing of fusion commonly occurs in crocodilians and many nonavian archosaurs (Fig. 1), and this possibly synapomorphic character in the phylogenetic frame is also discussed.

\section{Patency of Neurocentral Fusion during Crocodilian Postnatal Ontogeny}

Bipolar structure of neurocentral synchondrosis. Alligator has bipolar structure of the neurocentral synchondrosis, consisting of the three types of the cartilaginous zones (Fig. 8). The cartilage cells grow from the mid-zone towards the dorsal and ventral zones of the neurocentral synchondroses (i.e., towards the neural arch and centrum, respectively). In contrast, newly formed bone cells (osteoblasts) occur along the outermost boundaries of the neurocentral junctions. Around the neurocentral junction, bone cells from the centra and neural arches and cartilage cells from the neurocentral sutures compete to occupy for space (Fig. 10).

This bipolar cell structure has not been studied extensively in vertebrae of other vertebrates, but very similar morphology has been reported in craniofacial bones of mammals that remain open into very late postnatal ontogenetic periods (Opperman et al., 2005). The bipolar organization of cranial synchondrosis structurally differs from the unipolar arrangement of the cartilage cells in epiphyseal growth plates (e.g., the ends of mammalian limb bones, vertebral bodies; Bick and Copel, 1950; Fawcett, 1994), which rarely retain patency throughout the life span. It is suggested here that bipolar organization of cartilage cells at the neurocentral junction is in some way related to sutural patency persisting into late ontogenetic stages.

Vertical cell migration. Besides positive allometric change in the articular surface area of the neurocentral junctions (Table 4), another evident ontogenetic change is the vertically complex articulations (e.g., zigzagged and/or interdigitated boundaries). This increase in the vertical dimension of articular surface area, which is more evident in the dorsal vertebrae than in caudal vertebrae (Fig. 7), results in a more complex topography of contact between centrum and neural arch. The increased "complexity" of contact at the neurocentral articular surfaces leads to a richer array of contacts between cen- trum and neural arch, which is predicted to be biomechanically more stable under a variable loading regime than a flat articulation of equal surface area.

The phenomenon of the increased complexity must be the result of migration or pushing of bone cells from both sides of the centra and neural arches along the neurocentral synchondrosis (Fig. 8). This forced movement of the bone cells is reported as the cause of interdigitation in various facial and cranial sutures. In rats, clumping of osteoblasts particularly occurs in the convex side of a synchondroid suture, but fewer (or none of) osteoblast cells appear in the concave side of sutures (Hall, 1972; Koskinen et al., 1976; Cohen, 2000). Seemingly, the same kind of cell migrations occur in the neurocentral junctions of Alligator, which provide environments for increasing suture complexity in the presacral vertebrae.

Relationship between suture morphology and fusion timing. Generally, the relationship between complex sutures and patency of fusion exist in craniofacial bones of mammals (Byron, 2006). While synchondroid sutures are growing (increasing complexity), neighboring bones remain unfused. Thus, complex sutures generally indicate relatively late timing of fusion or patency through ontogeny. Cell-level morphology indicates this general pattern in mammalian craniofacial sutures apply to the neurocentral synchondroid joints in the presacral vertebrae of crocodilians.

Controlling factors for the timing of endochondral ossification of the neurocentral synchondroses have not yet been studied extensively in vertebrates. In general, the mechanism of sutural fusion is complicated and various factors are involved. Combinations of intrinsic (e.g., vascular, genetic, hormonal), extrinsic (e.g., mechanical), and epigenetic factors have been suggested in some craniofacial sutures in various mammals (e.g., Herring, 1993). Some specific genes have been identified for the mechanism of both patent and fused sutures (Opperman, 2000; Hall, 2005). These findings are extremely important for the understanding of the mechanism of sutural growth because the patterns of fusion in those craniofacial sutures can be homologous across different groups of mammals and possibly other vertebrates. However, in vertebral sutures, such a study-detecting controlling factors of neurocentral fusion-has not yet been fully explored. Christ et al. (2000) reported that a series of Pax and $M s x$ genes control endochondral ossification for large proportions of the centra and the base of neural arches in chickens and mice. Because neurocentral fusion is the result of ossification of the synchondrosis, Pax-1 and/or Pax-4 may be involved for the occurrence of this phenomenon, but further investigations are certainly needed.

\section{Comments on Archosaur Synapomorphies}

Fused centra and neural arches are known in mature individuals of most fishes, amphibians, mammals, and reptiles, and it may be hypothesized that this is a vertebrate synapomorphy. However, some aspects of the neurocentral synchondrosis differ among vertebrates. The neurocentral synchondrosis in Alligator is possibly secondary cartilage (Fig. 6), which has been suggested to be phylogenetically restricted in mammals and birds (and one species of teleosts; Benjamin, 1989; Hall, 2005, chapter 5). Also, fused centra and neural arches in extant 
frogs and salamanders are suggested directly to develop from mesenchymal cells, meaning no synchondroid cartilage ever forms at the neurocentral junction during life, but, perhaps, only fully fused centra and neural arches appear (Smith, 1960, p.146; also personal interpretation in Pugener and Maglia, 1997, 2009). These differences in the neurocentral synchondrosis could be interpreted two ways: (1) they provide evidence for the independent origin of the neurocentral synchondrosis; or (2) they represent modifications of the basal vertebrate condition that occurred within vertebrate subgroups. Similarly, delayed timing of neurocentral fusion, associated with bipolar cell structure and complex sutural boundaries in the neurocentral junction, is present in archosaurs (Fig. 1) and mammals. To evaluate these hypotheses of homology, data of cell-level morphology of the neurocentral junctions from various vertebrates will be necessary.

\section{CONCLUSIONS}

1. Neurocentral fusion (neurocentral suture closure) is the result of endochondral ossification, which is a physical change of the synchondroid cartilage into bone (Fig. 7). Four stages of fusion are established primarily based on the relation of the timing of endochondral ossification among the centra, the neural arches, and the neurocentral synchondroses in Alligator (Fig. 10).

2. Alligator mississippiensis has considerably delayed timing (i.e., after reaching sexual maturity and/or body size ca. $40 \%$ from the upper range in the species) of neurocentral fusion during postnatal ontogeny (Fig. 5). Fusion progresses from the posterior caudal to sacral vertebrae along a unidirectional posterior-to-anterior sequence, even after reaching sexual maturity. In the presacral vertebrae, complete fusion rarely occurs, indicating patency persisting throughout postnatal ontogeny. Fusion may occur in the dorsal vertebrae of very mature individuals, but this morphological change seems to occur in relatively short time during the postnatal growth. The cervical vertebrae fuses last in crocodilians.

3. Internal morphology of the neurocentral junction (i.e., unfused, partially fused, and fused) links to external suture morphology (i.e., open, partially closed, and closed statuses) (Figs. 2 and 9).

4. The neurocentral synchondrosis in crocodilians possibly belongs to secondary cartilage (Fig. 6), which has not been previously reported in any other nonavian reptiles, but further investigation is needed to confirm this hypothesis.

5. Bipolar cartilaginous cell structure is present in the neurocentral synchondrosis of Alligator. This cartilaginous cell organization seems to provide appropriate environments for increased complexity of sutural boundaries between centra and neural arches, which may link to delaying neurocentral fusion. Postnatal ontogenetic changes of external neurocentral suture morphology in extant and fossil alligators are currently under a study by the author.

6. The complex articulations, characterized by curved, zigzagged, and/or interdigitated sutural boundaries, between centra and neural arches and late neurocentral fusion in the presacral vertebrae commonly occur in crocodilians. The two features are synapomorphies, possibly extended to their Mesozoic close relatives, such as nonavian dinosaurs and pseudosuchians (or crurotarsans). Evolutionary distributions of the two features in fossil archosaurs, including Triassic archosauriformes, pseudosuchians (or crurotarsans), and nonavian dinosaurs, are currently under a study by the author.

\section{ACKNOWLEDGEMENTS}

The author owed a lot to his dissertation supervisor, Jeff Wilson (University of Michigan Museum of Paleontology). Other committee, Tom Baumiller, Ron Nussbaum, Janice Pappas, and Bill Sanders provided constructive comments and criticism. Special thanks go to Greg Schneider (UMMZ) for discussion and encouragement of this project. Fresh alligator vertebrae were generously donated to UMMZ for this study by Ruth Elsey (Louisiana Department of Wildlife and Fisheries, Rockefeller Wildlife Refuge, Grand Chenier), Allan "Woody" Woodward (Fish and Wildlife Research Laboratory in Gainesville, Florida), and Kenny Krysko (Florida Museum of Natural History, Herpetology). Chris Strayhorn (UM Dentistry School) helped for histological preparation. Moises Kaplan (UMMZ) also gave me some technical comments for histological preparation. Photos were taken under microscope at the histology lab of the Dentistry School and the Catherine Badgley's lab at the Museum of Paleontology at The University of Michigan. Curators and collection managers at the following institutions allowed me to examined osteological and fossil specimens: American Museum of Natural History (Herpetology, Vertebrate Paleontology), Institut für Paläontologie Museum für Naturkunde, Field Musuem of Natural History (Reptiles and Amphibians), Florida Museum of Natural History (Herpetology, Vertebrate Paleontology), Louisiana State University (School of Veterinary Medicine), Royal Tyrell Museum of Paleontology, Texas Memorial Museum University of Texas, University of Michigan Museeum of Zoology, University of Michigan Museum of Paleontology, and United State National Museum (Reptiles and Amphibians). Anonymous reviewers provided helpful advice and criticism.

\section{LITERATURE CITED}

Abramoff MD, Magelhaes PJ, Ram SJ. 2004. Image processing with ImageJ. Biophotonics Int 11:36-42.

Benjamin M. 1989. The development of hyaline-cell cartilage in the head of the black molly, Poecilia sphenops. Evidence for secondary cartilage in a teleost. J Anat 164:145-154.

Bick EM, Copel JW. 1950. Longitudinal growth the human vertebra. J Bone Joint Surgery 32:803-814.

Brochu CA. 1996. Closure of neurocentral sutures during crocodilian ontogeny: implications for maturity assessment in fossil archosaurs. J Vert Paleontol 16:49-62.

Byron CD. 2006. Role of the osteoclast in cranial suture waveform patterning. Anat Rec:552-563.

Carrano MT, Hutchinson JR, Sampson SD. 2005. New information on Segisaurus halli, a small theropod dinosaur from the Early Jurassic of Arizona. J Vert Paleontol 25:835-849.

Carrano MT, Sampson SD, Forster CA. 2002. The Osteology of Masiakasaurus knopfleri, a small abelisauroid (Dinosauria: 
Theropoda) from the Late Cretaceous of Madagascar. J Vert Paleontol 22:510-534.

Carpenter K. 1997. A giant coelophysoid (Ceratosauria) theropod from the Upper Triassic of New Mexico, USA. Neues Jahrb Geol Pal Abh 205:189-208.

Carr TD, Williamson TE, Schwimmer DR. 2005. A new genus and species of tyrannosauroid from the Late Cretaceous (middle Campanian) Demopolis Formation of Alabama. J Vert Paleontol 25:119-143.

Christ B, Huang R, Scaal M. 2007. Amniote somite derivatives. Devel Dynamics 236:2382-2396.

Christ B, Huang R, Wilting J. 2000. The development of the avian vertebral column. Anat Embryol 202:179-194.

Cohen MM, Jr. 2000. Sutural biology. In: Cohen MM, Jr, MacLean RE, editors. Craniosynostosis. Diagnosis, evaluation, and management. 2nd ed. New York: Oxford University Press. p 9-23.

Cole A, Fedak T, Hall B, Olson W, Vickaryous M. 2003. Sutures joining ontogeny and fossils. Palaeontol Assoc Newsletter 52:29-32.

Currie PJ, Chen P. 2001. Anatomy of Sinosauropteryx prima from Liaoning northeastern China. Can J Earth Sci 38:1705-1727.

Currie PJ, Zhiming D. 2001. New information on Shanshanosaurus huoyanshanensis, a juvenile tyrannosaurid (Theropoda, Dinosauria) from the Late Cretaceous of China. Can J Earth Sci 38: 1729-1737.

Dingerku G, Uhlers LD. 1977. Enzyme clearing of alcian blue stained whole small vertebrates for demonstration of cartilage. Biotech Histochem 52:229-232.

Farlow JO, Hurlburt GR, Elsey RM, Britton ARC, Langston W, Jr. 2005. Femoral dimensions and body size of Alligator mississippiensis: estimating the size of extinct mesoeucrocodylians. J Vert Paleontol 25:354-369.

Fawcett DW. 1994. Bloom and Fawcett: a textbook of histology. 12th ed. New York: Chapman \& Hall. p 964.

Ferguson MWJ. 1985. Reproductive biology and embryology of the crocodilians. In: Gans C, Billett F, Maderson PFA, editors. Biology of the reptilia volume 14, development A. New York: Wiley. p 329-491.

Frey E. 1988. Anatomie des Körperstammes von Alligator mississip. piensis Daudin. Stuttgarter Beitr Naturk A 424:1-106.

Hall BA. 1972. Immobilization and cartilage transformation into bone in the embryonic chick. Anat Rec 173:391-403.

Hall BA. 2005. Bones and cartilage: developmental and evolutionary skeletal biology. New York: Elsevier Academic Press. p 760.

Herring SE. 1993. Epigenetic and functional influences on skull growth. In: Hanken J, Hall BK, editors. The Skull Volume 1 development. Chicago: University of Chicago Press. p 153-206.

Higgins GM. 1923. Development of the primitive reptilian vertebral column, as shown by a study of Alligator mississippiensis. Am J Anat 31:373-406.

Hoffstetter R, Gasc JP. 1969. Vertebrae and ribs of modern reptiles. In: Gans C, Bellairs A, Persons TS, editors. Biology of the reptilia. Vol. 1. New York: Academic Press. p 201-310.

Ikejiri T. 2007. Ontogenetic and intracolumnar variation in the complexity of the neurocentral suture in dwarf and large crocodilian species. J Vert Paleontol 27 (Suppl 3):93-94A.

Ikejiri T, Tidwell V, Trexler DL. 2005. New adult specimens of Camarasaurus lentus highlights ontogenetic variation within the species. In: Tidwell V,Carpenter K, editors. Thunder-lizards: the sauropodomorph dinosaurs. Bloomington: Indiana University Press. p 154-179.

Irmis RB. 2007. Axial skeleton ontogeny in the Parasuchia (Archosauria: Pseudosuchia) and its implications for ontogenetic determination in archosaurs. J Vert Paleontol 25:350-361.
Koskinen L, Isotupa K, Koski K. 1976. A note on craniofacial sutural growth. Am J Phys Anthropol 45:511-516.

Kutty TS, Chatterjee S, Galton PM, Upchurch P. 2007. Basal sauropodomorphs (Dinosauria: Saurischia) from the Lower Jurassic of India: their anatomy and relationships. J Vert Paleontol 81: $1218-1240$.

Matt GJR, Matricali B, Meerten ELP. 1996. Postnatal development and structure of the neurocentral junction: its relevance for spinal surgery. Spine 21:661-666.

Mook CC. 1921. Notes on the postcranial skeleton in the Crocodilia. Bull Am Mus Nat Hist 44:67-100.

Opperman LA. 2000. Cranial sutures as intramembranous bone growth sites. Dev Dynamics 219:472-485.

Opperman LA, Gakunga PT, Carlson DS. 2005. Genetic factors influencing morphogenesis and growth of sutures and synchondroses in the craniofacial complex. Semin Orthod 11:199-208.

Pugener LA, Maglia AM. 1997. Osteology and skeletal development of Discoglossus sardus (Anura: Discoglossidae). J Morphol 233:267-286.

Pugener LA, Maglia AM. 2009. Skeletal morphogenesis of the vertebral column of the miniature hylid frog Acris crepitans, with comments on anomalies. J Morphol 270:52-69.

Rajwani T, Bagnall KM, Lambert R, Huang EM, Secretan C, Moreau M, Mahood J, Raso VJ, Bhargava R. 2005. Evaluating MRI as a technique for visualizing the neurocentral junction. Spine 30:807-812.

Rajwani T, Bhargava R, Moreau M, Mahood J, Raso JH, Jiang V, Bagnall KM. 2002. MRI characteristics of the neurocentral synchondrosis. Pediatric Radiol 32:811-816.

Rasband W. 2003. Image J version 1.31. National Institutes of Health. Maryland: Bethesda.

Rieppel O. 1993. Studies on skeleton formation in reptiles. v. Patterns of ossification in the skeleton of Alligator mississippiensis Daudin (Reptilia, Crocodylia). Zool J Linn Soc 109:301-325.

Schwarz D, Ikejiri T, Breithaup B, Klein N, Sander PM. 2007. A nearly complete skeleton of an early juvenile diplodocid (Dinosauria: Sauropoda) from the Lower Morrison Formation (Late Jurassic) of north central Wyoming and its implications for early ontogeny and pneumaticity in sauropods. Hist Biol 19:225-253.

Smith HM. 1960. Evolution of chordate structure. An introductory to comparative anatomy. Holt, Rinehart and Winston: New York.

Suzuki D, Weishampel DB, Minoura M. 2004. Nipponosaurus sachalinensis (Dinosauria; Ornithopoda). Anatomy and systematic position within hadrosauridae. J Vert Paleontol 24:145-164.

Tereshchenko VS. 2001. Sexual dimorphism in the postcranial skeleton of Protoceratopsids (Neoceratopsoa, Protoceratopsidae) from Mongolia. Paleontol J 35:415-425.

Tidwel V, Carpenter K. 2003. Braincase of an early Cretaceous titonosauriform sauropod from Texas. J Vert Paleontol 23:176-180.

Vital JM, Beguiristain JL, Algara C, Villas C, Lavignolle B, Grenier N, Sénégas J. 1989. The neurocentral vertebral cartilage: anatomy, physiology and physiopathology. Surgical Radiol Anat 11:323-328.

Wilkinson PM, Rhodes WE. 1997. Growth rates of American alligators in coastal South Carolina. J Wildlife Management 61: 397-402.

Williams EE. 1959. Gadow's arcualia and the development of tetrapod vertebrae. Quart Rev 34:1-32.

Yamazaki A, Mason DE, Caro PA. 1998. Age of closure of the neurocentral cartilage in the thoracic spine. J Pediat Orthoped 18: 168-172. 